Article

\title{
The Role of a Key Amino Acid Position in Species-Specific Proteinaceous dUTPase Inhibition
}

\author{
András Benedek 1,2,*, Fanni Temesváry-Kis ${ }^{1}$, Tamjidmaa Khatanbaatar ${ }^{1}$, Ibolya Leveles ${ }^{1,2}$, \\ Éva Viola Surányi ${ }^{1,2}$, Judit Eszter Szabó ${ }^{1,2}$, Lívius Wunderlich ${ }^{1}$ and Beáta G. Vértessy ${ }^{1,2, *}$ \\ 1 Budapest University of Technology and Economics, Department of Applied Biotechnology and Food Science, \\ H -1111 Budapest, Szent Gellért tér 4, Hungary; f.temesvary@gmail.com (F.T.-K.); \\ tamjidmaab3@gmail.com (T.K.); leveles.ibolya@ttk.mta.hu (I.L.); suranyi.eva@ttk.mta.hu (É.V.S.); \\ szabo.judit.eszter@ttk.mta.hu (J.E.S.); wunderlich@mail.bme.hu (L.W.) \\ 2 Research Centre for Natural Sciences, Hungarian Academy of Sciences, H-1117 Budapest, Magyar tudósok \\ körútja 2, Hungary \\ * Correspondence: abenedek@mail.bme.hu (A.B.); vertessy@mail.bme.hu (B.G.V.)
}

Received: 14 May 2019; Accepted: 27 May 2019; Published: 6 June 2019

\begin{abstract}
Protein inhibitors of key DNA repair enzymes play an important role in deciphering physiological pathways responsible for genome integrity, and may also be exploited in biomedical research. The staphylococcal repressor StlSaPIbov1 protein was described to be an efficient inhibitor of dUTPase homologues showing a certain degree of species-specificity. In order to provide insight into the inhibition mechanism, in the present study we investigated the interaction of StlSaPlbov1 and Escherichia coli dUTPase. Although we observed a strong interaction of these proteins, unexpectedly the E. coli dUTPase was not inhibited. Seeking a structural explanation for this phenomenon, we identified a key amino acid position where specific mutations sensitized E. coli dUTPase to StlSaPIbov1 inhibition. We solved the three-dimensional (3D) crystal structure of such a mutant in complex with the substrate analogue dUPNPP and surprisingly found that the C-terminal arm of the enzyme, containing the P-loop-like motif was ordered in the structure. This segment was never localized before in any other E. coli dUTPase crystal structures. The 3D structure in agreement with solution phase experiments suggested that ordering of the flexible C-terminal segment upon substrate binding is a major factor in defining the sensitivity of E. coli dUTPase for StlSaPlbov1 inhibition.
\end{abstract}

Keywords: dUTPase; trimer; inhibition; StlSaPlbov1; crystal structure; C-terminal arm

\section{Introduction}

Preservation of genome integrity is of utmost importance for all living organisms. Several complex pathways including numerous enzymes are involved in this duty. Among these, dUTPase and uracil DNA glycosylase enzymes are responsible for keeping DNA uracil-free [1-3]. Absence of dUTPase (in differentiated tissues, knock-out models or several microorganisms) [4-9] or its inhibition combined with thymidylate synthase-targeted chemotherapies $[10,11]$ is expected to lead to an increased level of uracil in DNA. Under such circumstances, DNA polymerases may readily incorporate uracil into DNA and uracil excision repair is activated. However, if dUTP levels are consistently high, repair cannot be completed efficiently because uracils will again be built into DNA via repair synthesis. Therefore, dUTPase inhibition leads to futile cycles of incomplete repair and may result in increased mutation rate, double strand breaks and thymine-less cell death [12-14].

Thymine-less cell death is a clinically significant pathway in tumor chemotherapy where it is usually induced by drugs acting on enzymes being involved in de novo thymidylate biosynthesis (eg. thymidylate synthase or dihydrofolate reductase) $[15,16]$. Due to the suboptimal response rate of the 
presently used drugs, development of novel anti-cancer strategies acting on the thymidylate synthesis route is of high significance [17]. The enzyme dUTPase is tightly connected to this pathway, as dUMP is the sole precursor of de novo deoxythymidine triphosphate (dTTP) biosynthesis [14]. Targeting dUTPase by small molecular drugs for cancer treatment has already been reported [13]. This enzyme is also a potential target of future antimicrobiotics against important pathogens such as Mycobacterium tuberculosis [7] or Plasmodium falciparum [18], as invading pathogen microorganisms require intensive DNA synthesis before cell replication [19].

We recently discovered another potential route for perturbing dUTPase action via a protein

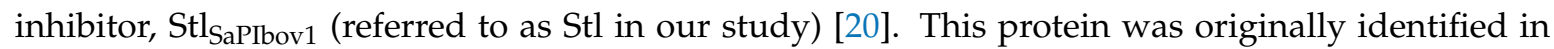
Staphylococcus aureus where its primary function is to repress the transcription of genes being responsible for excision and replication of $S$. aureus pathogenicity islands (SaPi-s). Its protein interaction partners in S. aureus are phage dUTPases such as the $\Phi 11$ and $80 \alpha$ phage trimeric dUTPases [21]. Upon binding to each other, the primary function of the two proteins is mutually abolished. Namely, in the $\Phi 11$ phage dUTPase:Stl complex, Stl is not able to repress transcription of the pathogenicity island protein genes and catalytic activity of the $\Phi 11$ phage dUTPase is practically abolished [20].

Previous publications of our research group showed that protein Stl has a potent cross-species inhibitory effect on some other trimeric dUTPase homologues from Mycobacteria, Drosophila and human sources as well [22-24]. Efficiency of Stl-induced inhibition on dUTPase activity varies among the complexes with different trimeric dUTPase homologues, and the exact structural background of these species-specific differences in Stl binding are yet to be investigated in details. The in-depth structural explanation for the alterations in inhibitory capacity would present a major step forward in the future development of species-specific dUTPase inhibitory peptides or peptide-mimicking small molecules [19]. Stl may also be a useful tool for an in vivo study of the effects of the elimination of dUTPase activity. The understanding of the structural background of species-specific inhibitory effect of Stl on different dUTPases would make it possible to predict whether Stl will be applicable as a tool to study a given dUTPase in vivo.

In our previous studies, we reported insights into Stl-inhibition of dUTPases from staphylococcal, human, mycobacterial and Drosophila sources [20,22-24]. We observed a generally valid inhibition pattern characterized by a strong dUTPase:Stl complex with dissociation constant in the nanomolar range, and provided a detailed elucidation of the molecular mechanism of interaction and inhibition for the $\Phi 11$ dUTPase:Stl system [20]. However, a full understanding of the structural biology of the Stl-dUTPase complex is not yet available, since on the one hand crystallization trials of the complex have not yet been successful, and on the other hand the molecular size of the complex prevents high-resolution nuclear magnetic resonance (NMR) studies. For the protein Stl, no experimentally determined three-dimensional (3D) structure has yet been published. In silico homology modelling of the Stl structure accompanied by synchrotron radiation circular dichroism studies suggested a protein fold mostly containing alpha-helices [25]. For the protein dUTPase, there are numerous high-resolution dUTPase crystal structures deposited in the Protein Data Bank (PDB) (reviewed eg. in [2]). These structures all show the well-conserved dUTPase jelly-roll fold; however, there are some structural variations. Interestingly, in the Escherichia coli dUTPase structures deposited so far very few residues from the C-terminal arm of the enzyme can be localized, probably due to high conformational flexibility in this region [26]. The dUTPase C-terminal arm was previously shown to play some, although not essential role in Stl binding [20,27]. In the present work, we extended our Stl inhibition studies to E. coli dUTPase, since from this aspect it seems to be different from the $\Phi 11$ bacteriophage, human or mycobacterial enzymes for which Stl inhibition was observed [28-30].

Here we show that E. coli dUTPase and protein Stl form a strong protein complex associated with nanomolar dissociation constant. Unexpectedly, we also found that Stl inhibition of E. coli dUTPase in steady-state activity measurements could not be observed, therefore this enzyme presents a potentially useful model for further understanding of the governing factors leading toward dUTPase inhibition by Stl. Based on previous structural data we initiated a series of rationally designed mutations to reveal 
the key components involved in inhibition. Two such mutations were successfully identified (mutation of the 93rd glutamine to either histidine or arginine, abbreviated as EcDUT ${ }^{\mathrm{Q} 93 \mathrm{H}}$ and EcDUT Q93R, respectively). We found that both of these mutant $E$. coli dUTPases were significantly inhibited by Stl. We have also crystallized the EcDUT ${ }^{\mathrm{Q} 93 \mathrm{H}}$ mutant in complex with a non-hydrolysable substrate analogue, $\alpha, \beta$-imido-dUTP (dUPNPP) and solved the 3D structure of this complex. The detailed structural information combined with solution experiments provided insights into the potential role of C-terminal arm flexibility and Stl-induced inhibition.

\section{Materials and Methods}

\subsection{Site-Directed Mutagenesis}

Site-directed mutagenesis was carried out based on either the original QuikChange mutagenesis protocol (Agilent Technologies, Santa Clara, CA, USA) or on a modified version using only partially overlapping primers [31]. The sequence of the primers used in our polymerase chain reactions (PCRs) is listed in Table 1.

Table 1. List of primers used for site-directed mutagenesis. Mismatched nucleotides are marked with red letters.

\begin{tabular}{|c|c|}
\hline Q93H_FW & 5' GATCGATTCTGACTATCATGGCCAGTTGATGATTTCC $3^{\prime}$ \\
\hline Q93H_REV & 5' GGAAATCATCAACTGGCCATGATAGTCAGAATCGATC 3' \\
\hline Q93R_fw & 5' GACTATCGGGGCCAGTTGATGATTTCCGTGTGG 3' \\
\hline Q93R_rev & 5' CTGGCCCCGATAGTCAGAATCGATCAATCCTACCAGG 3' \\
\hline E114D_fw & 5' CATTCAACCTGGCGATCGCATCGCCCAG 3' \\
\hline E114D_rev & 5' CTGGGCGATGCGATCGCCAGGTTGAATG 3' \\
\hline R115K_fw & 5' CCTGGCGAAAAAATCGCCCAGATGATTTTTGTTCCGGTAGTACAGGCTGAATTTAATCTGGTGG 3' \\
\hline R115K_rev & 5' CTGGGCGATTTTTTCGCCAGGTTGAATGGTGAAGCTGTCCTGACCACGG 3' \\
\hline ER114-5DK_fw & 5' CAACCTGGCGATAAAATCGCCCAGATGATTTTTGTTCCGGTAGTACAGGCTGAATTTAATCTGGTGG 3' \\
\hline ER114-5DK_rev & 5' CATCTGGGCGATTTTATCGCCAGGTTGAATGGTGAAGCTGTCCTGACCACGG 3' \\
\hline F145W_fw & 5' GAAGGCGGCTGGGGTCACTCTGGTCGTCAGTAACACATACGGATCCGGC 3' \\
\hline F145W_rev & 5' AGAGTGACCCCAGCCGCCTTCACCGCGGTCGGTGGCGTC 3' \\
\hline H147S_fw & 5' CCGCGGTGAAGGCGGCTTTGGTAGCTCTGGTCGTCAGTAACAC 3' \\
\hline H147S_rev & 5' GTGTTACTGACGACCAGAGCTACCAAAGCCGCCTTCACCGCGG 3' \\
\hline
\end{tabular}

\subsection{Molecular Cloning, Protein Expression and Purification}

The gene encoding protein Stl was expressed from a pGEX-4T-1 vector (GE Healthcare, Chicago, Illinois, USA) as a glutathione S-transferase (GST)-fused construct. The GST-tag was cleaved from the protein via overnight thrombin digestion during its purification process [24]. The E. coli dUTPase gene was inserted into a pET-15b vector (Merck KGaA, Darmstadt, Germany) between the BamHI and NdeI cleavage sites to enable its expression with an N-terminal His-tag which was used in further purification steps [32]. Both protein Stl and our E. coli dUTPase constructs were expressed in E. coli BL21 (DE3) Rosetta cells (Novagen) and they were purified according to our previously used protocol [24].

\subsection{Size Exclusion Chromatography}

For this measurement, an AKTA FPLC purification system with a Superose 12 10/300 GL column (GE Healthcare) was used. EcDUT, protein Stl and their 1:1 monomeric molar ratio mixture were injected on the column in dUTPase buffer (20 mM HEPES (4-(2-hydroxyethyl)-1-piperazineethanesulfonic acid), $300 \mathrm{mM} \mathrm{NaCl}, 5 \mathrm{mM} \mathrm{MgCl}$, 10mM $\beta$-mercaptoethanol, $\mathrm{pH}=7.5$ ). Peak elution volumes of the three separate injections were compared and plotted on the same graph. 


\subsection{Differential Scanning Fluorimetry (Thermofluor)}

Samples were heated from 25 to $85^{\circ} \mathrm{C}$ in a BioRad CFX96 Touch instrument (Hercules, CA, USA) using three parallels of each measurement in $25 \mu \mathrm{L}$ volumes. EcDUT and protein Stl were used in 1:1 molar ratio in their mixture and single protein concentrations were set to $40 \mu \mathrm{M}$, corresponding to monomeric protein subunits. Sypro Orange dye (ThermoFisher Scientific, Waltham, MA, USA) was added to the samples in 1000-fold dilution to follow protein unfolding. Melting points were determined as the extremum values corresponding to the first negative derivate of the melting curve (cf. [24]).

\subsection{Multiple Sequence Alignment Based Mutational Screen}

The dUTPase protein sequences were obtained from the Protein Data Bank and the UniProt database [33,34]. Sequence alignments were carried out using the Clustal Omega server [35]. Conserved dUTPase sequence motifs were identified based on earlier studies on dUTPases [2,26]. Recent hydrogen deuterium exchange-mass spectrometry (HDX-MS) measurements on the interaction surface of human dUTPase and protein Stl were also taken into consideration in the sequence alignment [23].

\subsection{Measurement of Steady-State Enzyme Activity and Inhibition}

The by-product of dUTP hydrolysis is a proton released which causes a change in the $\mathrm{pH}$ of the reaction mixture. Adding phenol-red indicator to the reaction buffer ( $1 \mathrm{mM} \mathrm{HEPES,} 150 \mathrm{mM} \mathrm{KCl}, 5 \mathrm{mM}$ $\mathrm{MgCl}_{2}, 40 \mu \mathrm{M}$ phenol red, $\mathrm{pH}=7.5$ ) enables quantification of dUTP hydrolysis. Change in absorbance upon dUTP addition was followed at $559 \mathrm{~nm}$ at $20^{\circ} \mathrm{C}$. Quasi steady-state velocity $\left(\mathrm{v}_{0}\right)$ was determined by fitting a curve to the linear phase of the progress line. Stl inhibition measurements were carried out after 5 min pre-incubation of the Stl-dUTPase mixture at $20^{\circ} \mathrm{C}$. The concentration of dUTPase was kept constant at $50 \mathrm{nM}$, while Stl concentration varied between 0 and $400 \mathrm{nM}$. Always $30 \mu \mathrm{M}$ dUTP was used to initiate the enzymatic reaction after pre-incubation of the proteins. Three parallels were measured in each cases [24]. For plotting relative $k_{c a t}$ values, propagation of standard errors was taken into consideration according to the following formula:

$$
\mathrm{SD}_{\mathrm{F}}^{2}=\frac{\mathrm{k}_{\mathrm{cat}, 400}^{2}}{\mathrm{k}_{\text {cat, } 0}^{2}} *\left(\frac{\mathrm{SD}_{400}^{2}}{\mathrm{k}_{\mathrm{cat}, 400}^{2}}+\frac{\mathrm{SD}_{0}^{2}}{\mathrm{k}_{\mathrm{cat}, 0}^{2}}\right)
$$

where $\mathrm{SD}_{\mathrm{F}}$ is the propagated standard deviation, $\mathrm{k}_{\mathrm{cat}, 0 \text { and }} \mathrm{k}_{\mathrm{cat}, 400}$ is the catalytic rate constant in absence and presence of $400 \mathrm{nM} \mathrm{Stl}$, and $\mathrm{SD}_{0}$ and $\mathrm{SD}_{400}$ are their respective standard deviations.

A quadratic equation was fitted on the Stl inhibition curves of the EcDUT ${ }^{\mathrm{Q} 3 \mathrm{H}}$ and EcDUT ${ }^{\mathrm{Q} 93 \mathrm{R}}$ mutants according to the following formula:

$$
y=s+\frac{A\left[(c+x+K)-\sqrt{(c+x+K)^{2}-4 c x}\right]}{2 c}
$$

where $y$ is the (relative) steady-state enzyme activity, $x$ is protein Stl's concentration, $s$ is the (relative) steady-state enzyme activity without Stl addition, A is the total decrease in (relative) steady-state activity, $c$ is dUTPase concentration (kept constant) and $K$ is the $K_{i}\left(\mathrm{IC}_{50}\right)$ value which is the output parameter obtained from curve fitting.

\subsection{Isothermal Titration Calorimetry}

Isothermal tritation calorimetry (ITC) experiments were carried out at $20^{\circ} \mathrm{C}$ on a Microcal ITC200 instrument (Malvern Instruments, Malvern, UK). The proteins were dialysed against a buffer $\mathrm{pH}=7.5$ comprising $20 \mathrm{mM}$ HEPES, $300 \mathrm{mM} \mathrm{NaCl}$ and $1 \mathrm{mM}$ TCEP. We used 22-57 $\mu \mathrm{M}$ Stl in the cell and 330-550 $\mu \mathrm{M}$ enzyme (EcDUT, EcDUT $\left.{ }^{\mathrm{Q} 93 \mathrm{H}}, \mathrm{EcDUT}^{\mathrm{Q} 93 \mathrm{R}}\right)$ in the syringe. Both protein concentrations 
correspond to monomeric subunits. The titrations were performed with the injection syringe rotating at $750 \mathrm{rpm}$ (revolutions per minute) and included a series of 20 injections spaced $180 \mathrm{~s}$ apart from each other, with injection volumes of $0.5 \mu \mathrm{L}$ for the first titration and $2 \mu \mathrm{L}$ for the subsequent 19 titrations. The data were analyzed using Microcal Origin software following the directions of the manufacturer (Malvern Panalytical Ltd, Malvern, UK). The one set of independent sites binding model was applied to data for determination of thermodynamic parameters: dissociation constant (Kd), stoichiometry $(\mathrm{N})$, enthalpy $(\Delta \mathrm{H})$ and entropy $(\Delta S)$. The mean and standard deviation (SD) of the parameters were calculated from three independent experiments.

\subsection{Protein Crystallization and Structural Refinement}

EcDUTQ93H was gel filtrated in $20 \mathrm{mM}$ HEPES, $100 \mathrm{mM} \mathrm{NaCl}, 5 \mathrm{mM} \mathrm{MgCl}$, pH = 7.5 (gel filtration buffer) and then immediately concentrated to $43 \mathrm{mg} / \mathrm{mL}$ and mixed with $5 \mathrm{mM}$ dUPNPP before crystallization. The enzyme-dUPNPP complex was incubated on ice for at least 30 min before being mixed with the reservoir solution (0.1 M TRIS, 18-33.75\% polyethylene glycol 3350, $400 \mathrm{mM}$ $\mathrm{NaAc}, \mathrm{pH}=7.5$ ) in 2:1 or 1:1 protein-reservoir ratios. Crystals were grown with hanging drop vapor diffusion method at 295 K. Data were collected at the European Synchrotron Radiation Facility (ESRF, Grenoble, France) at Beamline ID30A-3. For data collection, a cryoprotectant containing $12 \%$ glycerol was used. For data processing and scaling, the XDS program package was used [36].

The crystal structure was solved by molecular replacement using a wild-type E. coli dUTPase crystal structure in complex with dUPNPP (PDB-ID:1RN8) as a template [26]. For structural refinement, the program packages PHENIX and CCP4 were used [37-40]. Data collection and refinement statistics are summarized in Table 2. Three monomers are present in the asymmetric unit. Coordinates and crystal factor data are deposited in Protein Data Bank with the identification code 6HDE. Figures were created using PyMOL [41].

Table 2. Data collection and refinement statistics for the EcDUT ${ }^{\mathrm{Q} 93 \mathrm{H}}$ structure (PDB-ID:6HDE).

\begin{tabular}{|c|c|}
\hline Data Collection & Parameters \\
\hline Space group & P 212121 \\
\hline Unit-cell parameters $\left(\mathrm{A}^{\circ}\right)$ & $\mathrm{a}=63.20, \mathrm{~b}=66.50, \mathrm{c}=95.30$ \\
\hline Unit-cell parameters (angles) & $\alpha=\beta=\gamma=90^{\circ}$ \\
\hline Resolution range $\left(\mathrm{A}^{\circ}\right)$ & $45.811-1.8$ \\
\hline Total No. of reflections & 113402 \\
\hline No. of unique reflections & 36491 \\
\hline Completeness (\%) & 99.2 \\
\hline$<\mathrm{I} / \sigma(\mathrm{I})>$ & 1.64 (at $1.82 \AA)$ \\
\hline Rmeas & 0.043 \\
\hline \multicolumn{2}{|l|}{ Refinement } \\
\hline No. of dUTPase subunits in asymmetric unit & 3 \\
\hline No. of protein atoms & 3257 \\
\hline No. of ligand atoms & 84 \\
\hline No. of waters & 162 \\
\hline No. of $\mathrm{Mg}^{2+}$ ions & 3 \\
\hline Rcryst/Rfreeł & $0.1806 / 0.2209$ \\
\hline Average B factors $\left(\AA^{2}\right)$ (all atoms) & 33.0 \\
\hline Wilson B factor $\left(\AA^{2}\right)$ & 27.4 \\
\hline
\end{tabular}


Table 2. Cont.

\begin{tabular}{cc}
\hline Data Collection & Parameters \\
\hline Protein atoms & 3257 \\
\hline Ligand atoms & 84 \\
\hline Water & 162 \\
\hline $\mathrm{Mg}^{2+}$ ions & 3 \\
\hline R.m.s. deviations from ideal values & 0.007 \\
\hline Bond lengths (A $\left.{ }^{\circ}\right)$ & 1.01 \\
\hline Bond angles $\left(^{\circ}\right)$ & \\
\hline Ramachandan plot analysis, residues in (\%) & 96.97 \\
\hline Favoured region & 3.03 \\
\hline Allowed region & 0.00 \\
\hline Disallowed region
\end{tabular}

\subsection{Tryptophan Fluorimetry}

Samples of $3 \mu \mathrm{M}$ dUTPase in $20 \mathrm{mM}$ HEPES, $300 \mathrm{mM} \mathrm{NaCl}, 5 \mathrm{mM} \mathrm{MgCl} 2, \mathrm{pH}=7.5$ were prepared. Protein Stl or dUPNPP were added in $4.5 \mu \mathrm{M}$ or $100 \mu \mathrm{M}$ final concentration, respectively. Tryptophan fluorescence spectra were recorded at $293 \mathrm{~K}$ on a Jobin Yvon Spex FluoroMax-3 spectrofluorometer (Horiba France SAS, Palaiseau, France) between $300 \mathrm{~nm}$ and $400 \mathrm{~nm}$, using $295 \mathrm{~nm}$ excitation wavelength. Excitation and emission slits were set to $1 \mathrm{~nm}$ and $5 \mathrm{~nm}$, respectively. Fluorescence spectrum of the assay buffer was subtracted from all protein spectra to eliminate additional fluorescence or inner filter effects.

\subsection{Acrylamide Quenching and Statistical Analysis}

Acrylamide quenching was measured on a BioTek Synegry MX plate reader (BioTek Instruments, Inc. Winooski, Vermont, USA) on 96-well plates in $25 \mu \mathrm{L}$ final volumes using $4 \mu \mathrm{M}$ dUTPase concentration. Both the EcDUT ${ }^{\mathrm{F} 145 \mathrm{~W}}$ and $\mathrm{EcDUT}^{\mathrm{Q} 93 \mathrm{H}, \mathrm{F} 145 \mathrm{~W}}$ enzymes were measured in order to compare their C-terminal arm movements. A titration of the enzyme, enzyme-dUPNPP, enzyme-Stl or $\mathrm{N}$-acetyl-L-tryptophanamide (NATA) solutions was carried out with high purity acrylamide (Sigma-Aldrich, cat. no.: A9099, subsidiary of Merck KGaA, St. Louis, Missouri, USA) in 0-0.40 $\mu \mathrm{M}$ concentration range on three parallel plates ensuring three independent titration curves of the compared protein samples. Samples were excited at $295 \mathrm{~nm}$ and their emission was measured at $338 \mathrm{~nm}$. Protein Stl or dUPNPP was added to the respective samples in $6 \mu \mathrm{M}$ or $1.5 \mathrm{mM}$ final concentration. Fluorescence of the acrylamide solution itself was subtracted from all titration curves. A modified Stern-Volmer equation was fitted to the titration curves (Equation (3)).

$$
\frac{\mathrm{F}_{0}}{\mathrm{~F}}=1+\mathrm{K}_{\mathrm{SV}} *[\mathrm{Q}] * \mathrm{e}^{\mathrm{V}[\mathrm{Q}]}
$$

In the equation $\mathrm{F}_{0}$ is the unquenched and $\mathrm{F}$ is the quenched tryptophan fluorescence, $\mathrm{Q}$ is the quencher (acrylamide), $\mathrm{K}_{\mathrm{sv}}$ is the dynamic (bimolecular) quenching constant and $\mathrm{V}$ is the static (sphere of action) component of quenching [42-44].

Analysis of variance (ANOVA) was carried out on the obtained $\mathrm{K}_{\mathrm{sv}}$ data by using Statistica 13 software. The ANOVA was followed by two planned comparisons ( $t$ tests) between the apo and dUPNPP-bound states of the EcDUT ${ }^{\mathrm{F} 145 \mathrm{~W}}$ and EcDUT ${ }^{\mathrm{Q} 93 \mathrm{H}, \mathrm{F145W}}$ enzymes. Significance level was set at $5 \%$ using two-sided $p$ values. 


\section{Results and discussion}

\subsection{Stl Binds to Escherichia coli dUTPase but Does Not Show Inhibitory Potential in Steady-State Kinetic Experiments}

To decide whether Stl may bind to E. coli dUTPase (EcDUT) we have performed a size-exclusion chromatographic experiment. Figure 1A shows that a mixture of Stl and EcDUT elutes from the size-exclusion chromatographic column in a symmetric single peak, clearly separate from the elution peaks of Stl or EcDUT alone. This peak is associated with a lower elution volume (i.e. higher molecular weight) arguing for the formation of a protein-protein complex. Complexation of these two proteins was also investigated using differential scanning fluorimetry for both the components (Stl and EcDUT) and their mixture (complex). Differential scanning fluorimetry (also known as thermofluor) is a straightforward method to follow the thermal denaturation profile of proteins on their own or in complexes and to determine their melting temperature $\left(T_{m}\right)$ [45]. As shown on Figure 1B, EcDUT and Stl show different $\mathrm{T}_{\mathrm{m}}$ values $\left(70.5^{\circ} \mathrm{C}\right.$ and $52.0^{\circ} \mathrm{C}$, respectively), whereas the $\mathrm{T}_{\mathrm{m}}$ observed in their complex is $57.0^{\circ} \mathrm{C}$.

A

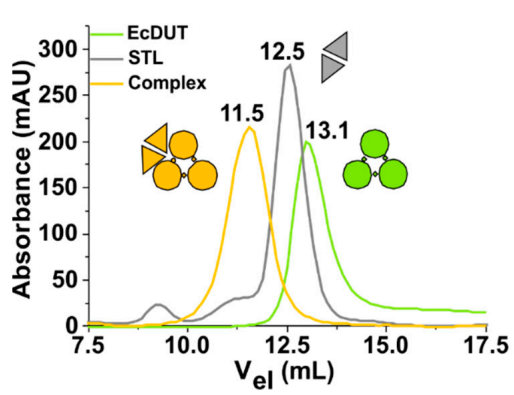

B

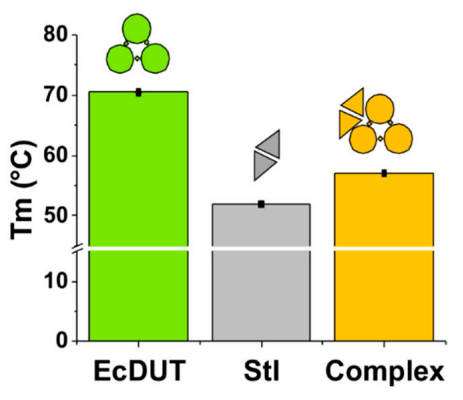

Figure 1. Complex formation between EcDUT and Stl. Data and symbols for EcDUT, Stl and their mixtures are shown in green, grey, and yellow colors, respectively. Pictograms show the oligomeric assembly characteristic for each species. (A) Size-exclusion chromatography. Peak elution volumes are marked with numbers (data in $\mathrm{mL}$ ) above the elution peaks. (B) Differential scanning fluorimetry. Melting points are plotted as mean values with standard deviations (less than $0.5{ }^{\circ} \mathrm{C}$ for all measurement replicates).

Having established the potential of complex formation between EcDUT and Stl, we next investigated if the enzymatic activity of dUTPase is inhibited in the protein complex. For several dUTPases from different sources, Stl was reported to show an inhibitory effect on dUTPase activity [20,22-24]. It was therefore unexpected to observe that addition of Stl to the reaction mixture during steady-state enzyme activity measurements did not result in an inhibitory pattern (see data on Figure 2A,B).

\subsection{Searching for Key Residues in Inhibition and Identification of Such a Position}

It was of immediate interest to determine the structural background for this unexpected lack of inhibition of EcDUT by Stl. Towards this end we started with investigation of differences in the primary structure of EcDUT as compared to all the other dUTPases where Stl was shown to be a protein inhibitor (Figure 2C). Our rational was to locate residues that are conserved in all the other dUTPases which are inhibited by Stl, but not in EcDUT. We also included residues suggested to be relevant in this aspect from comparisons between the complexes formed by Stl and different phage dUTPases $(80 \alpha$ and $\Phi 11$ phage dUTPases) [27]. These residues are indicated on a green background on Figure $2 \mathrm{C}$. We then performed rationally designed mutations where the residue in the EcDUT protein was exchanged for the residue observed in another dUTPase inhibitable by Stl. Results are shown on Figure 2A and are also summarized on the inset table of Figure 2B. 
A

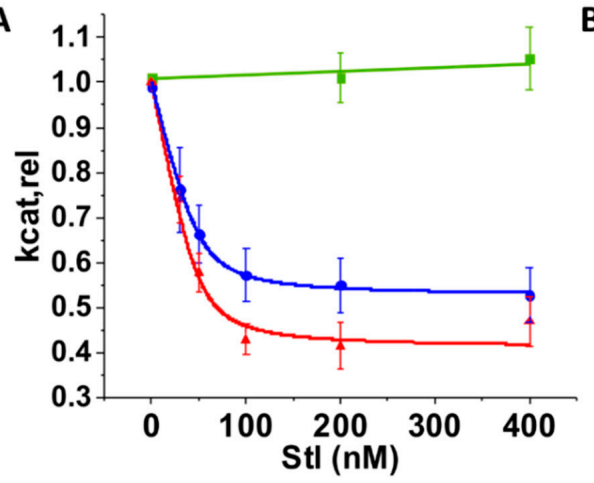

\begin{tabular}{|c|c|}
\hline EcDUT : Stl complex & $\mathbf{k}_{\text {cat, rel }}$ \\
\hline EcDUT : Stl & $0.96 \pm 0.08$ \\
\hline EcDUT $^{\mathrm{Q} 93 \mathrm{H}}:$ Stl & $0.47 \pm 0.06$ \\
\hline EcDUT $^{\text {Q93R }}:$ Stl & $0.53 \pm 0.06$ \\
\hline EcDUT $^{\text {E114D }}:$ Stl & $1.00 \pm 0.03$ \\
\hline EcDUT $^{\text {E114D, R115K }}:$ Stl & $1.05 \pm 0.12$ \\
\hline EcDUT $^{\mathrm{H} 147 \mathrm{~S}}: \mathrm{Stl}$ & $1.07 \pm 0.03$ \\
\hline EcDUT $^{\mathrm{F} 145 \mathrm{~W}}: \mathrm{Stl}$ & $1.15 \pm 0.09$ \\
\hline EcDUT $^{\mathrm{Q} 93 \mathrm{H}, \mathrm{F} 145 \mathrm{~W}}: \mathrm{Stl}$ & $0.68 \pm 0.09$ \\
\hline $\mathrm{EcDUT}^{\mathrm{Q} 93 \mathrm{R}, \mathrm{F} 145 \mathrm{~W}}: \mathrm{Stl}$ & $0.54 \pm 0.06$ \\
\hline
\end{tabular}

C

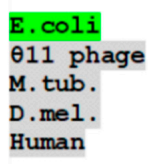

E. coli

$\theta 11$ phage

M. tub.

D. mel.

Human

E. coli

011 phage

M. tub.

D. mel.

Human

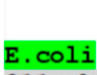

$\theta 11$ phage

M. tub.

D.mel.

Human

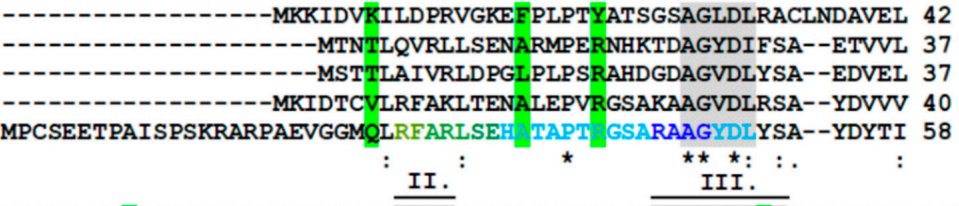

APGDTTLVPTGLAIHIADPSLAAMMLPRSGLGHKHGIVLGNLVGLIDSDYQGQLMISVWN 102 EPOEKAVIKTDVAVS IPEGY-VGLLTSRSGVSSKTHL--VIETGKIDAGYHGNLGINIKN 94 APGRRALVRTGVAVAVPFGM-VGLVHPRSGLATRVGLSIVNSPGTIDAGYRGEIKVALIN 96 PARGKAIVKTDLQVQVPEGS-YGRVAPRSGLAVKNFI--DVGAGVVDEDYRGNLGVVLFN 97 PPMEKAVVKTDIQIALPSGC-YGRVAPRSGLAAKHFI--DVGAGVIDEDY GNVGVVLFN 115 $:: \star^{\star} .:::_{\text {IV. }}$

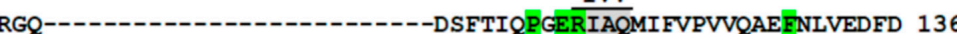
DIASNGYITPGVFDIKGEIDLSDAIROYGTYOINEGDKLAQLVIVPIWTPELKOVEEFE 154 LDP-------------------AAPIVVHRGDRIAQLLVQRVELVELVEVSSFD 131 HSD----------------V-DFEVKHGDRIAQFICERIFYPQLVMVDKLE 131 FGK------------ KFEVKKGDRIAQLICERIFYPEIEEVQALD 149

$\mathrm{V}$. $\therefore \star \star:: \star \star:: \quad: \quad:: \quad \star,::$

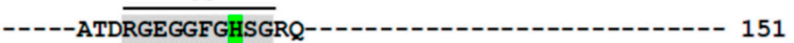

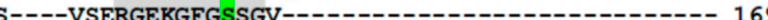

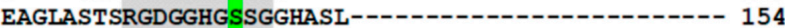

----DTERGEAGFGSTGVKDLPAAKAQNGNGEKAAEPEGAAPAPVAT 174

---DTERGSGGFG TGKN-----

. $\star \star \star \star \star * *$

Figure 2. Identification of key residues in dUTPase inhibition upon Stl binding. (A) Stl inhibits the EcDUT ${ }^{\mathrm{Q} 93 \mathrm{H}}$ and $\mathrm{EcDUT}^{\mathrm{Q} 93 \mathrm{R}}$ point mutants but not the wild-type EcDUT. Steady-state activities of EcDUT (green), EcDUT ${ }^{\mathrm{Q} 93 \mathrm{R}}$ (blue) and $\mathrm{EcDUT}^{\mathrm{Q} 93 \mathrm{H}}$ (red) against Stl concentration are plotted on the graph. A quadratic equation was fitted on the inhibitable enzymes, from which $\mathrm{K}_{\mathrm{i}}\left(\mathrm{IC}_{50}\right)$ values were calculated. $\mathrm{K}_{\mathrm{i}}$ was measured to be $4.83 \pm 3.46 \mathrm{nM}$ for EcDUT ${ }^{\mathrm{Q} 93 \mathrm{H}}$ and $5.90 \pm 0.73$ for EcDUTQ93R, respectively. (B) Relative $\mathrm{k}_{\text {cat }}$ values of EcDUT constructs upon $400 \mathrm{nM}$ Stl addition, referred to the activity measured without Stl addition. For standard deviation values, propagation of uncertainty upon normalization was taken into consideration (cf. Materials and Methods). (C) Multiple sequence alignment comparing the non-inhibitable (Escherichia coli) and inhibitable ( $\Phi 11$ phage, Mycobacterium tuberculosis, Drosophila melanogaster, human) dUTPases. Conserved dUTPase sequence motifs contributing for active site architecture are numbered (I-V) and shown on grey background. Altered side-chain characteristics of EcDUT compared to the inhibitable dUTPases are shown on green background. Interaction surface of human dUTPase with protein Stl determined by recent hydrogen/deuterium exchange-mass spectrometry (HDX-MS) measurements is highlighted on the human dUTPase sequence with the same color code as it was published in ref. [23].

Several of these mutations (EcDUT ${ }^{\mathrm{E} 114 \mathrm{D}}, \mathrm{EcDUT}^{\mathrm{E} 114 \mathrm{D}, \mathrm{R} 115 \mathrm{~K}}, \mathrm{EcDUT}^{\mathrm{H} 147 \mathrm{~S}}$ ) did not lead to any observable inhibition by Stl. However, we could successfully locate one specific position (EcDUT ${ }^{\mathrm{Q} 3}$ ) where mutation of the glutamine side-chain either into histidine or arginine led to strong inhibition of dUTPase activity by Stl (Figure 2A,B). Histidine at this position was found in the $\Phi 11$ dUTPase, whereas in M. tuberculosis, Drosophila melanogaster and Homo sapiens dUTPases, arginine is present at this site. Interestingly, as shown in recent HDX-MS experiments [23], this side-chain position is located 
within a peptide segment involved in formation of the interaction surface of the human dUTPase-Stl protein complex.

The successful modification of the E. coli enzyme structure clearly resulted in a character being inhibitable by Stl, arguing for the key importance of the mutated residue position in the inhibitory mechanism. The two resulting mutant constructs $\left(\mathrm{EcDUT}^{\mathrm{Q} 93 \mathrm{H}}\right.$ and $\mathrm{EcDUT}^{\mathrm{Q} 93 \mathrm{R}}$ ) were both clearly inhibited by Stl and the inhibition resulted in a decrease of the steady-state velocity by $58 \%$ and $47 \%$, respectively.

We also wished to quantify the strength of interaction of the complexes of wild-type EcDUT and the mutant EcDUT constructs with Stl. Figure 3 shows the results of isothermal titration microcalorimetric experiments. Based on these data we observe that mutation of the 93rd glutamine position into either arginine or histidine increases the strength of interaction by approximately two-three fold. Although the $\mathrm{dG}$ values for the complexes involving the wild-type and the mutant dUTPases are very similar, it is important to note that $\mathrm{dH}$ values are significantly higher for the EcDUT ${ }^{\mathrm{Q} 93 \mathrm{H}}: \mathrm{Stl}$ and EcDUT ${ }^{\mathrm{9} 3 \mathrm{R}}$ :Stl complexes. This finding indicates the creation of additional favorable enthalpic interactions for these complexes (potential H-bonds, polar or Van der Waals interactions).

A

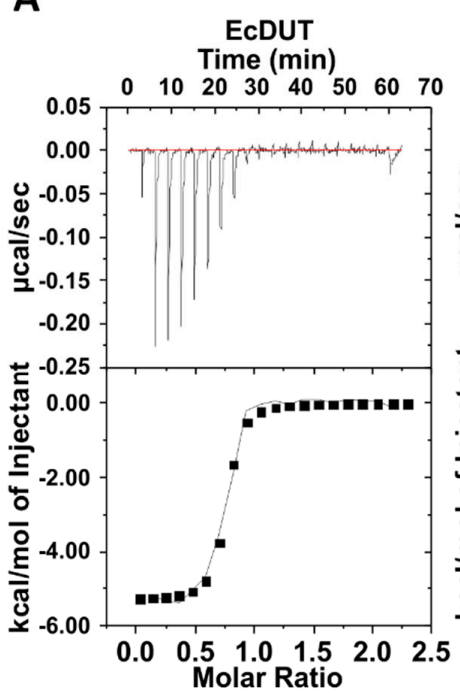

B

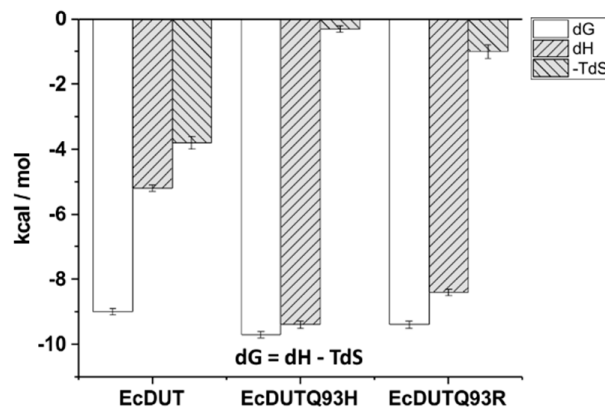

EcDUTQ93H Time (min)

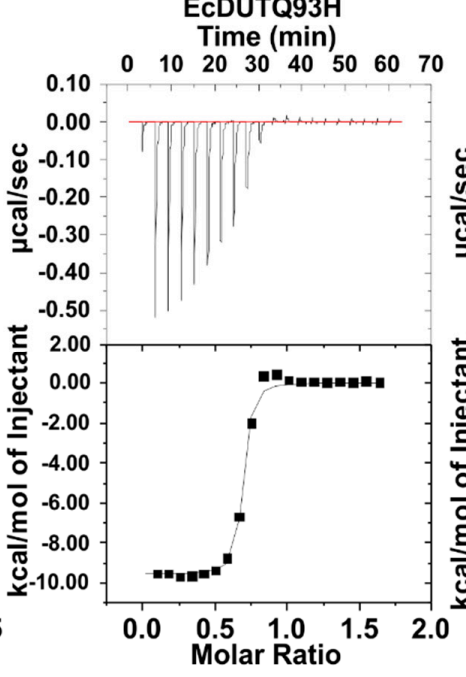

C

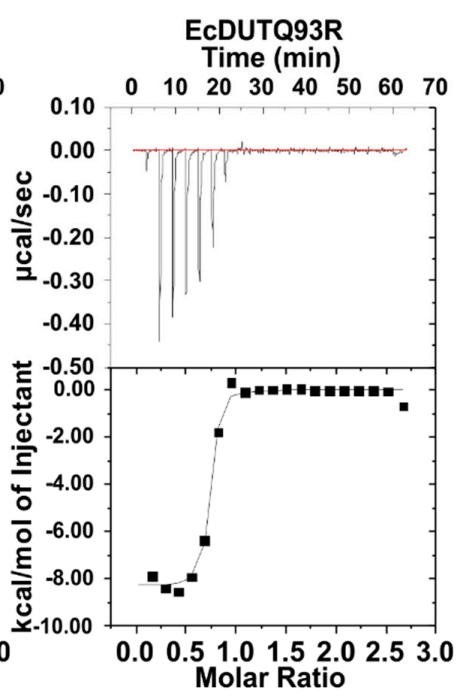

Molar Ratio

\begin{tabular}{|c|c|c|c|}
\hline & EcDUT & EcDUT $^{\text {Q93H }}$ & EcDUT $^{\text {Q93R }}$ \\
\hline n value & $0.7 \pm 0.0$ & $0.7 \pm 0.0$ & $0.7 \pm 0.0$ \\
\hline $\begin{array}{c}\Delta \mathbf{H} \\
(\mathbf{k c a l} / \mathbf{m o l})\end{array}$ & $-5.2 \pm 0.1$ & $-9.4 \pm 0.1$ & $-8.4 \pm 0.1$ \\
\hline $\begin{array}{c}-\mathbf{T} \mathbf{\Delta S} \\
(\mathbf{k c a l} / \mathbf{m o l})\end{array}$ & $-3.8 \pm 0.2$ & $-0.3 \pm 0.1$ & $-1.0 \pm 0.2$ \\
\hline $\begin{array}{c}\Delta \mathbf{G} \\
(\mathbf{k c a l} / \mathbf{m o l})\end{array}$ & $-9.0 \pm 0.1$ & $-9.7 \pm 0.1$ & $-9.4 \pm 0.1$ \\
\hline $\mathbf{K}_{\mathbf{d}} \mathbf{( n M )}$ & $199.2 \pm 25.0$ & $60.8 \pm 4.5$ & $97.2 \pm 10.7$ \\
\hline
\end{tabular}

Figure 3. Thermodynamic characterization of EcDUT:Stl complex formation. (A) Titration of EcDUT (left), EcDUT ${ }^{\mathrm{Q} 93 \mathrm{H}}$ (middle) and EcDUT ${ }^{\mathrm{Q} 93 \mathrm{R}}$ (right) with protein Stl. (B) and (C) Thermodynamic data of complex formation.

\subsection{Understanding the Structural Background of Inhibitablity}

It was of clear interest to understand the exact changes in the enzyme structure caused by the point mutations at the 93rd amino acid position. Therefore, we crystallized the EcDUTQ93H dUTPase mutant in the presence of the non-hydrolysable substrate analogue dUPNPP and compared its structure to the 
already deposited wild-type E. coli dUTPase structures (Figure 4). The 3D structure of the EcDUTQ93H dUTPase mutant (PDB ID 6HDE) is shown on Figure 4B-G.

A

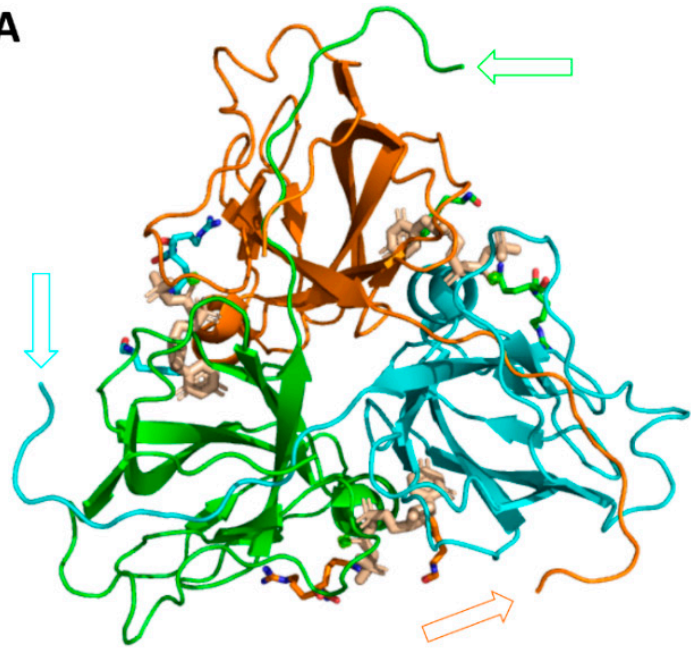

B

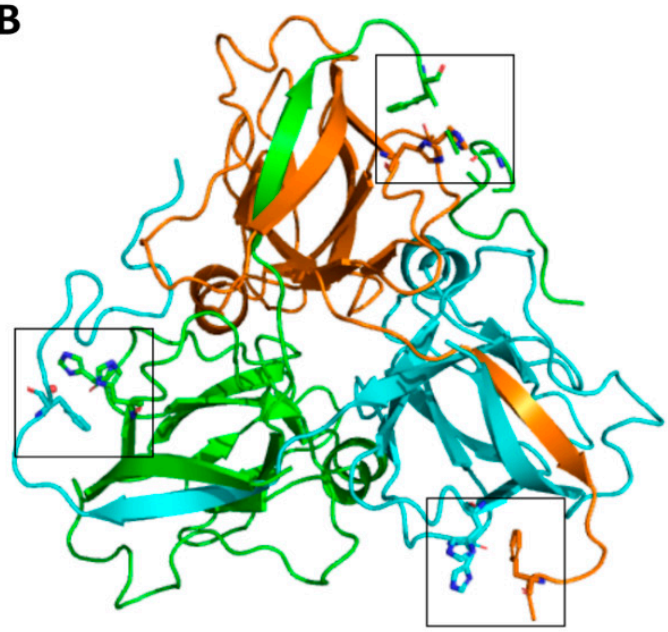

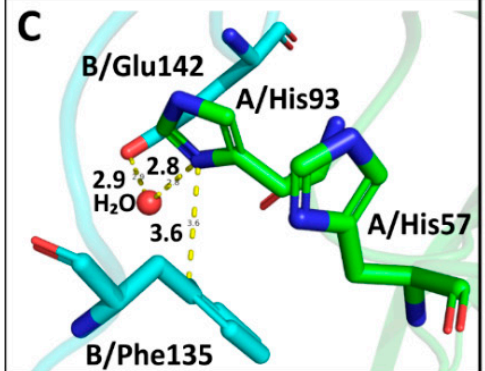
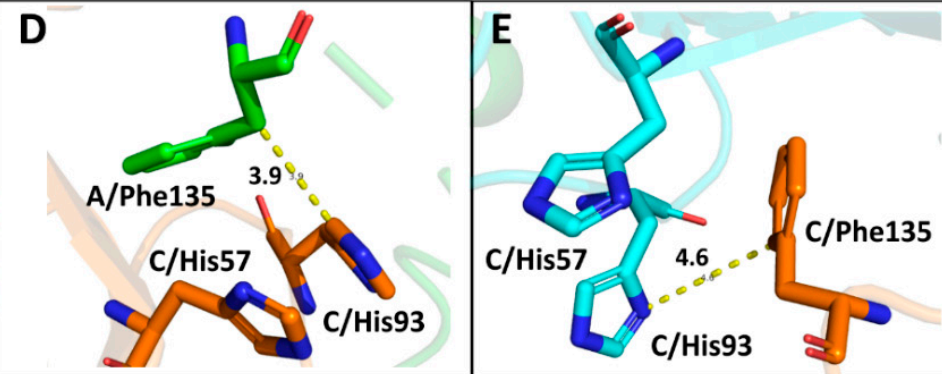

$\mathbf{F}$
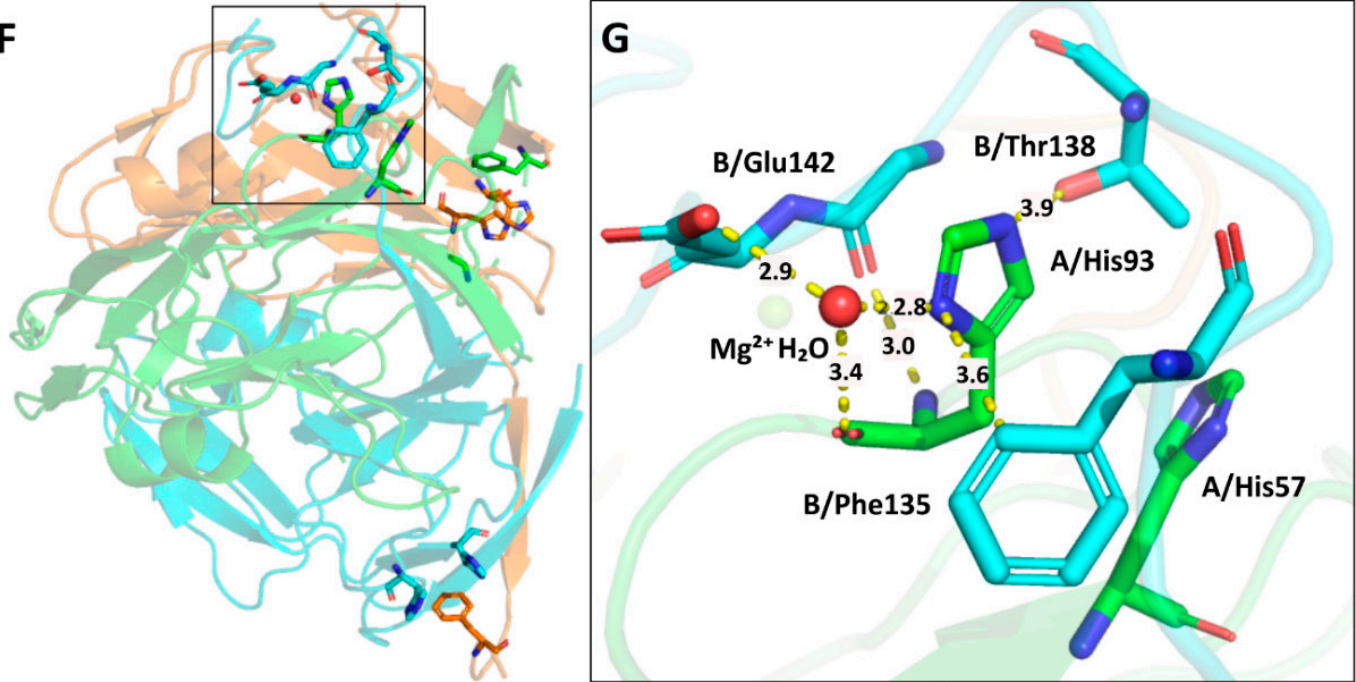

Figure 4. Structural insights into mutation-induced conformational changes. Subunits of the enzyme are color coded (orange, green, blue). The three dUPNPP molecules at the active sites are highlighted with wheat-colored sticks. (A) Wild-type EcDUT crystal structure (PDB-ID:1RN8) [26] that was used as a template in our molecular replacement. Missing parts of the C-terminal arms are indicated with empty arrows. Only F145, R150 and Q151 are visible out of the last 15 C-terminal residues of the 1RN8 model, visualized by line representation. (B) The presently determined EcDUT ${ }^{\mathrm{Q} 93 \mathrm{H}}$ crystal structure (PDB ID:6HDE). Positions of the mutated $\mathrm{H} 93$ residues are marked with boxes. (C), (D), (E) The point-mutant H93 side-chain can establish aromatic contacts with the C-terminal arm of the neighboring subunit. (F) The EcDUT ${ }^{\mathrm{Q} 93 \mathrm{H}}$ crystal structure from side-view. (G) A water-linked hydrogen-bonding contact between the mutated $\mathrm{H} 93$ residue and the Q142 side-chain of the C-terminal arm. 
A novelty of our structure is that the whole C-terminal arm of the enzyme is visible in one of the subunits, whereas major parts of the segment are also visible in the other two subunits. This part of the enzyme has central role in catalysis, however it was so far missing from all existing E. coli dUTPase structures, even if they were crystallized in the presence of a substrate analogue. Our crystal structure provides a strong implication for existing interactions among the histidine point mutation at the 93rd position and the C-terminal arm of the enzyme, serving with a straightforward explanation for increased visibility of the C-terminal arm section.

We hypothesized that the increased sensitivity of the EcDUT ${ }^{\mathrm{Q} 93 \mathrm{H}}$ and EcDUT ${ }^{\mathrm{Q} 93 \mathrm{R}}$ mutants for inhibition by protein Stl and their stronger Stl binding ability compared to the wild-type E. coli dUTPase is in connection with the restricted conformational freedom of the C-terminal arm of the enzyme.

To find further explanation for the fact that the EcDUT ${ }^{\mathrm{Q} 93 \mathrm{H}}$ and $\mathrm{EcDUT}{ }^{\mathrm{Q} 93 \mathrm{R}}$ point mutants can be readily inhibited by Stl, and to test our arm-flexibility hypothesis, we were intended to establish a technique to follow C-terminal arm movements upon substrate or Stl binding. Towards this end, we introduced a tryptophan point mutation into the C-terminal arms of the wild-type, EcDUTQ93H and $\mathrm{EcDUT}^{\mathrm{Q} 93 \mathrm{R}}$ mutant dUTPases, obtaining three additional enzyme variants, namely EcDUT ${ }^{\mathrm{F} 145 \mathrm{~W}}$, EcDUTQ93H, F145W and EcDUT Q93R, F145W.

The engineered Trp residue indeed allowed us to follow substrate analogue and Stl binding of the three arm-tryptophan mutant enzyme variants (Figure 5 and cf. Figure 2B) [28]. In comparison with earlier published studies we therefore confirm here that binding of the cognate ligand to the dUTPase active site is readily transmitted to decreased fluorescence intensity of the tryptophan fluorophore within the C-terminal arm [28,30,46] (cf. Figure 2A).

A

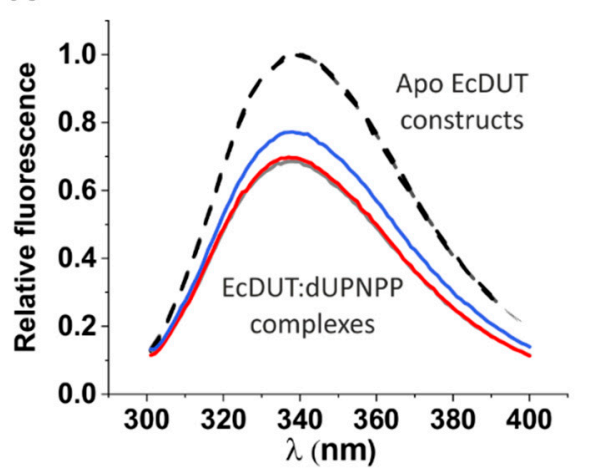

C
B

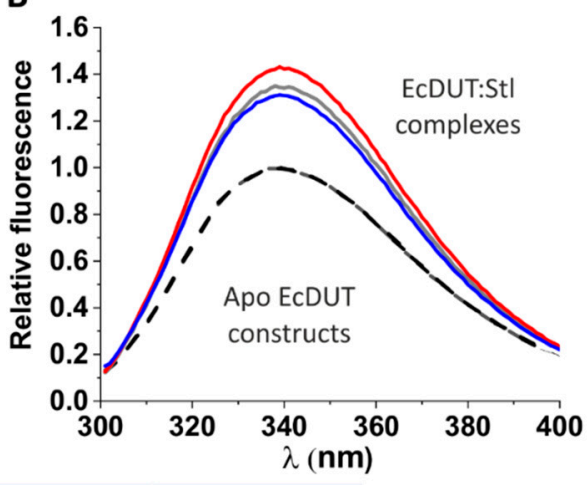

Stl

$$
\begin{array}{llll}
\text { EcDUT }^{\mathrm{F} 145 W} & 1 & 0.69 \pm 0.09 & 1.35 \pm 0.08 \\
\text { EcDUT }^{\mathrm{Q} 93 \mathrm{H}, \mathrm{F} 145 \mathrm{~W}} & 1 & 0.70 \pm 0.07 & 1.43 \pm 0.10 \\
\text { EcDUTT }^{\mathrm{Q} 93 \mathrm{R}, \mathrm{F} 145 \mathrm{~W}} & 1 & 0.76 \pm 0.03 & 1.33 \pm 0.07
\end{array}
$$

Figure 5. The active site tryptophan sensor reports on ligand binding to EcDUT. (A) Binding of the substrate analogue dUPNPP. (B) Binding of protein Stl. (C) Comparison of peak relative fluorescence values. Black dashed lines stand for the EcDUT ${ }^{\mathrm{F} 145 \mathrm{~W}}$, EcDUTQ93H,F145W and EcDUTQ93R,F145W apoenzyme constructs. Ligand bound EcDUT ${ }^{\mathrm{F} 145 \mathrm{~W}}$, EcDUTQ93H,F145W and EcDUTQ93R,F145W are represented by grey, red and blue straight lines, respectively.

To enable a more direct comparison of the arm movement behavior of our tryptophan sensor containing mutants, acrylamide quenching experiments were planned. The $\mathrm{K}_{\mathrm{sv}}$ constant values obtained by this method revealed that the quasi wild-type EcDUT ${ }^{\mathrm{F} 145 \mathrm{~W}}$ and EcDUTQ93H,F145W mutant enzymes are remarkably different in their arm movements upon dUPNPP substrate analogue binding (Figure 6A,B). Data from the quenching experiments clearly argue that solvent accessibility of the tryptophan residue in the EcDUT ${ }^{\mathrm{Q} 93 \mathrm{H}, \mathrm{F} 145 \mathrm{~W}}$ dUTPase - dUPNPP complex is decreased as compared to the complex formed with EcDUT ${ }^{\mathrm{F} 145 \mathrm{~W}}$. Difference in solvent accessibility $\left(\mathrm{K}_{\mathrm{sv}}\right.$ values) between the 
apo and dUPNPP-bound state of the EcDUT ${ }^{\mathrm{Q} 93 \mathrm{H}, \mathrm{F} 145 \mathrm{~W}}$ mutant enzyme was proved to be statistically significant ( $p=0.0073$, cf. Figure $6 \mathrm{~A})$, while in the case of the EcDUT ${ }^{\mathrm{F} 145 \mathrm{~W}}$ enzyme no significant difference was observed ( $p=0.5957$ ). We therefore conclude that the quenching experiments in the solution state provide re-enforcement for the restricted conformational flexibility of the C-terminus observed in the crystal structure.
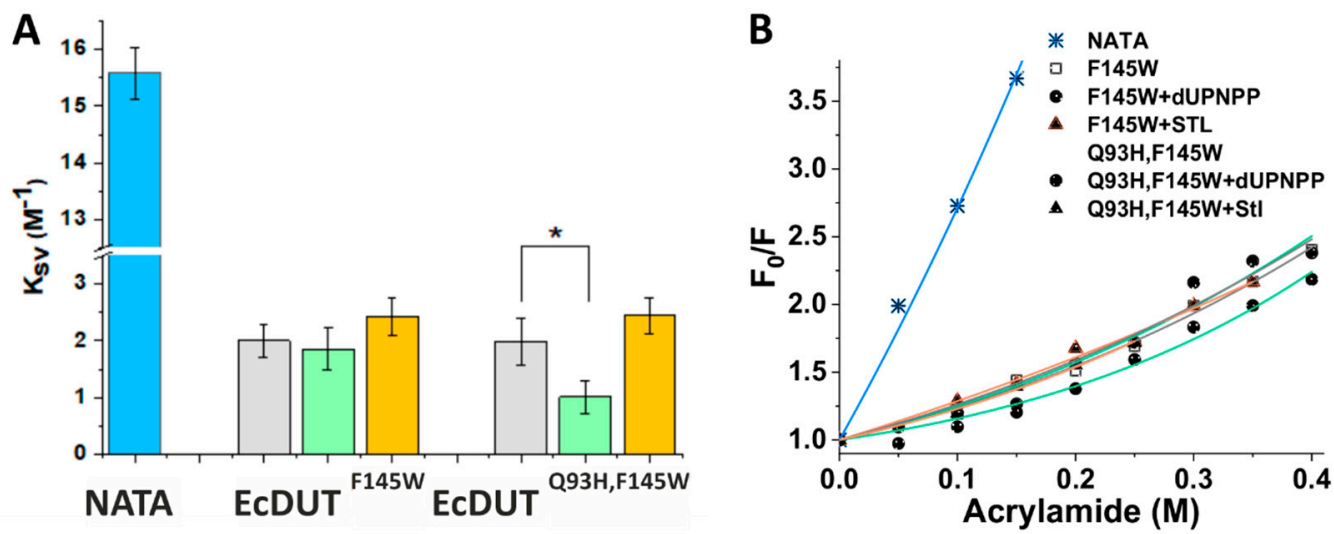

Figure 6. Acrylamide quenching reveals altered solvent accessibility upon mutation in EcDUT. (A) Comparison of quenching constants ( $\mathrm{K}_{\mathrm{sv}}$ values). Please note that lower $\mathrm{K}_{\mathrm{sv}}$ values argue for less solvent exposed C-terminal arms. Blue color refers to NATA solution (reference for the quenching constant of free tryptophan residues in the solution). The apo-state fluorescence of EcDUT ${ }^{\mathrm{F} 145 \mathrm{~W}}$ and EcDUT ${ }^{\mathrm{Q} 93 \mathrm{H}, \mathrm{F} 145 \mathrm{~W}}$ (green) was compared to their dUPNPP-bound (grey) and Stl-bound (orange) state. A star above the respective bars indicates that $\mathrm{K}_{\mathrm{sv}}$ difference between the apo- and dUPNPP-bound state is statistically significant for EcDUT ${ }^{\mathrm{Q} 93 \mathrm{H}}, \mathrm{F} 145 \mathrm{~W}$ but not for the EcDUT ${ }^{\mathrm{F} 145 \mathrm{~W}}$ enzyme construct. (B) $\mathrm{F}_{0} / \mathrm{F}$ values as a function of acrylamide concentration.

\section{Conclusions}

In conclusion, we have demonstrated that specific side-chain mutations dramatically alter the character of interaction between Stl and E. coli dUTPase. Namely, we have found that changing the wild-type glutamine into either arginine or histidine at the 93rd position leads to an enzyme variant which is strongly inhibited by Stl. We also found that these mutations alter the extent of orderliness in the C-terminal segment which is achieved by substrate binding to the E. coli enzyme. These data suggest a link between C-terminal arm flexibility and inhibition characteristics of E. coli dUTPase.

Author Contributions: Conceptualization: A.B., J.E.S., B.G.V. Data curation: A.B., I.L. Formal analysis: A.B.; Funding acquisition: B.G.V. Investigation: A.B., F.T.K., T.K., I.L., É.V.S., J.E.S., L.W. Methodology: A.B., F.T.K., T.K., I.L., É.V.S., J.E.S., L.W., B.G.V. Project administration: A.B. and B.G.V. Resources: B.G.V. Software: I.L. Supervision: B.G.V. Validation: A.B., F.T.K., T.K., É.V.S. Visualization: A.B., É.V.S., J.E.S., B.G.V. Writing - original draft, A.B., É.V.S., J.E.S., B.G.V. Writing - review \& editing: A.B., F.T.K., É.V.S., J.E.S., L.W., B.G.V.

Funding: This work was supported by the National Research, Development and Innovation Office of Hungary (K119493, NVKP_16-1-2016-0020, 2017-1.3.1-VKE-2017-00002, 2017-1.3.1-VKE-2017-00013, VEKOP-2.3.2-16-2017-00013 to BGV, NKP-2018-1.2.1-NKP-2018-00005), and the BME-Biotechnology FIKP grant of EMMI (BME FIKP-BIO). AB thanks the fellowship support from Gedeon Richter Plc, Hungary. JES was supported by the National Research, Development and Innovation Office (PD124330) and by the ÚNKP-18-4-BME-391 New National Excellence Program of The Ministry Of Human Capacities. JES is the recipient of the János Bolyai Research Scholarship of the Hungarian Academy of Sciences.

Acknowledgments: We gratefully acknowledge Ivana Kutá Smatanová and Pavlína Řezáčová for their early help in crystallization within the frame of the FEBS Practical Course "Advanced Methods in Macromolecular Crystallization VII" (Nove Hrady, 2016). We sincerely thank Dávid Kun for his help in statistical analysis. We thank Ágnes Tantos for offering her help in using their plate reader instrument for the acrylamide quenching measurements.

Conflicts of Interest: The authors declare no conflict of interest. The funders had no role in the design of the study; in the collection, analyses, or interpretation of data; in the writing of the manuscript, or in the decision to publish the results. 


\section{References}

1. Nagy, G.N.; Leveles, I.; Vertessy, B.G. Preventive DNA repair by sanitizing the cellular (deoxy)nucleoside triphosphate pool. FEBS J. 2014, 281, 4207-4223. [CrossRef] [PubMed]

2. Vertessy, B.G.; Toth, J. Keeping uracil out of DNA: Physiological role, structure and catalytic mechanism of dUTPases. Acc. Chem. Res. 2009, 42, 97-106. [CrossRef] [PubMed]

3. Krokan, H.E.; Bjoras, M. Base excision repair. Cold Spring Harb. Perspect. Biol. 2013, 5, a012583. [CrossRef] [PubMed]

4. Palinkas, H.L.; Racz, G.A.; Gal, Z.; Hoffmann, O.I.; Tihanyi, G.; Rona, G.; Gocza, E.; Hiripi, L.; Vertessy, B.G. CRISPR/Cas9-Mediated Knock-Out of dUTPase in Mice Leads to Early Embryonic Lethality. Biomolecules 2019, 9, 136. [CrossRef] [PubMed]

5. Gadsden, M.H.; McIntosh, E.M.; Game, J.C.; Wilson, P.J.; Haynes, R.H. dUTP pyrophosphatase is an essential enzyme in Saccharomyces cerevisiae. EMBO J. 1993, 12, 4425-4431. [CrossRef] [PubMed]

6. el-Hajj, H.H.; Zhang, H.; Weiss, B. Lethality of a dut (deoxyuridine triphosphatase) mutation in Escherichia coli. J. Bacteriol. 1988, 170, 1069-1075. [CrossRef] [PubMed]

7. Pecsi, I.; Hirmondo, R.; Brown, A.C.; Lopata, A.; Parish, T.; Vertessy, B.G.; Toth, J. The dUTPase enzyme is essential in Mycobacterium smegmatis. PLoS ONE 2012, 7, e37461. [CrossRef]

8. Muha, V.; Horvath, A.; Bekesi, A.; Pukancsik, M.; Hodoscsek, B.; Merenyi, G.; Rona, G.; Batki, J.; Kiss, I.; Jankovics, F.; et al. Uracil-containing DNA in Drosophila: Stability, stage-specific accumulation, and developmental involvement. PLoS Genet. 2012, 8, e1002738. [CrossRef]

9. Horvath, A.; Bekesi, A.; Muha, V.; Erdelyi, M.; Vertessy, B.G. Expanding the DNA alphabet in the fruit fly: Uracil enrichment in genomic DNA. Fly 2013, 7, 23-27. [CrossRef]

10. Wilson, P.M.; Danenberg, P.V.; Johnston, P.G.; Lenz, H.J.; Ladner, R.D. Standing the test of time: Targeting thymidylate biosynthesis in cancer therapy. Nat. Rev. Clin. Oncol. 2014, 11, 282-298. [CrossRef]

11. Wilson, P.M.; LaBonte, M.J.; Lenz, H.J.; Mack, P.C.; Ladner, R.D. Inhibition of dUTPase induces synthetic lethality with thymidylate synthase-targeted therapies in non-small cell lung cancer. Mol. Cancer 2012, 11, 616-628. [CrossRef] [PubMed]

12. Pearl, L.H.; Savva, R. The problem with pyrimidines. Nat. Struct. Biol. 1996, 3, 485-487. [CrossRef] [PubMed]

13. Doi, T.; Yoh, K.; Shitara, K.; Takahashi, H.; Ueno, M.; Kobayashi, S.; Morimoto, M.; Okusaka, T.; Ueno, H.; Morizane, C.; et al. First-in-human phase 1 study of novel dUTPase inhibitor TAS-114 in combination with S-1 in Japanese patients with advanced solid tumors. Investig. New Drugs 2018. [CrossRef] [PubMed]

14. Hirmondo, R.; Lopata, A.; Suranyi, E.V.; Vertessy, B.G.; Toth, J. Differential control of dNTP biosynthesis and genome integrity maintenance by the dUTPase superfamily enzymes. Sci. Rep. 2017, 7, 6043. [CrossRef] [PubMed]

15. Giovannetti, E.; Zucali, P.A.; Rolfo, C.; Assaraf, Y.G.; Peters, G.J. Prognostic and Predictive Roles of Thymidylate Synthase Expression in Lung Cancer: The Debate Is Still Open. J. Clin. Oncol. Off. J. Am. Soc. Clin. Oncol. 2016, 34, 511-512. [CrossRef] [PubMed]

16. Hagner, N.; Joerger, M. Cancer chemotherapy: Targeting folic acid synthesis. Cancer Manag. Res. 2010, 2, 293-301.

17. Yao, W.; Zhu, S.; Li, P.; Zhang, S. Large tumor suppressor kinase 2 overexpression attenuates 5-FU-resistance in colorectal cancer via activating the JNK-MIEF1-mitochondrial division pathway. Cancer Cell Int. 2019, 19, 97. [CrossRef]

18. Whittingham, J.L.; Leal, I.; Nguyen, C.; Kasinathan, G.; Bell, E.; Jones, A.F.; Berry, C.; Benito, A.; Turkenburg, J.P.; Dodson, E.J.; et al. dUTPase as a platform for antimalarial drug design: Structural basis for the selectivity of a class of nucleoside inhibitors. Structure 2005, 13, 329-338. [CrossRef]

19. Nyiri, K.; Vertessy, B.G. Perturbation of genome integrity to fight pathogenic microorganisms. Biochim. Biophys. Acta Gen. Subj. 2017, 1861, 3593-3612. [CrossRef]

20. Szabo, J.E.; Nemeth, V.; Papp-Kadar, V.; Nyiri, K.; Leveles, I.; Bendes, A.A.; Zagyva, I.; Rona, G.; Palinkas, H.L.; Besztercei, B.; et al. Highly potent dUTPase inhibition by a bacterial repressor protein reveals a novel mechanism for gene expression control. Nucleic Acids Res. 2014, 42, 11912-11920. [CrossRef]

21. Tormo-Mas, M.A.; Mir, I.; Shrestha, A.; Tallent, S.M.; Campoy, S.; Lasa, I.; Barbe, J.; Novick, R.P.; Christie, G.E.; Penades, J.R. Moonlighting bacteriophage proteins derepress staphylococcal pathogenicity islands. Nature 2010, 465, 779-782. [CrossRef] [PubMed] 
22. Hirmondo, R.; Szabo, J.E.; Nyiri, K.; Tarjanyi, S.; Dobrotka, P.; Toth, J.; Vertessy, B.G. Cross-species inhibition of dUTPase via the Staphylococcal Stl protein perturbs dNTP pool and colony formation in Mycobacterium. DNA Repair 2015, 30, 21-27. [CrossRef] [PubMed]

23. Nyiri, K.; Mertens, H.D.T.; Tihanyi, B.; Nagy, G.N.; Kohegyi, B.; Matejka, J.; Harris, M.J.; Szabo, J.E.; Papp-Kadar, V.; Nemeth-Pongracz, V.; et al. Structural model of human dUTPase in complex with a novel proteinaceous inhibitor. Sci. Rep. 2018, 8, 4326. [CrossRef] [PubMed]

24. Benedek, A.; Poloskei, I.; Ozohanics, O.; Vekey, K.; Vertessy, B.G. The Stl repressor from Staphylococcus aureus is an efficient inhibitor of the eukaryotic fruitfly dUTPase. FEBS Open Bio 2018, 8, 158-167. [CrossRef] [PubMed]

25. Nyiri, K.; Kohegyi, B.; Micsonai, A.; Kardos, J.; Vertessy, B.G. Evidence-Based Structural Model of the Staphylococcal Repressor Protein: Separation of Functions into Different Domains. PLoS ONE 2015, 10, e0139086. [CrossRef] [PubMed]

26. Barabas, O.; Pongracz, V.; Kovari, J.; Wilmanns, M.; Vertessy, B.G. Structural insights into the catalytic mechanism of phosphate ester hydrolysis by dUTPase. J. Biol. Chem. 2004, 279, 42907-42915. [CrossRef] [PubMed]

27. Maiques, E.; Quiles-Puchalt, N.; Donderis, J.; Ciges-Tomas, J.R.; Alite, C.; Bowring, J.Z.; Humphrey, S.; Penades, J.R.; Marina, A. Another look at the mechanism involving trimeric dUTPases in Staphylococcus aureus pathogenicity island induction involves novel players in the party. Nucleic Acids Res. 2016, 44, 5457-5469. [CrossRef]

28. Leveles, I.; Nemeth, V.; Szabo, J.E.; Harmat, V.; Nyiri, K.; Bendes, A.A.; Papp-Kadar, V.; Zagyva, I.; Rona, G.; Ozohanics, O.; et al. Structure and enzymatic mechanism of a moonlighting dUTPase. Acta Cryst. D Biol. Cryst. 2013, 69, 2298-2308. [CrossRef]

29. Varga, B.; Barabas, O.; Kovari, J.; Toth, J.; Hunyadi-Gulyas, E.; Klement, E.; Medzihradszky, K.F.; Tolgyesi, F.; Fidy, J.; Vertessy, B.G. Active site closure facilitates juxtaposition of reactant atoms for initiation of catalysis by human dUTPase. FEBS Lett. 2007, 581, 4783-4788. [CrossRef]

30. Varga, B.; Barabas, O.; Takacs, E.; Nagy, N.; Nagy, P.; Vertessy, B.G. Active site of mycobacterial dUTPase: Structural characteristics and a built-in sensor. Biochem. Biophys. Res. Commun. 2008, 373, 8-13. [CrossRef]

31. Liu, H.; Naismith, J.H. An efficient one-step site-directed deletion, insertion, single and multiple-site plasmid mutagenesis protocol. BMC Biotechnol. 2008, 8, 91. [CrossRef] [PubMed]

32. Benedek, A.; Horvath, A.; Hirmondo, R.; Ozohanics, O.; Bekesi, A.; Modos, K.; Revesz, A.; Vekey, K.; Nagy, G.N.; Vertessy, B.G. Potential steps in the evolution of a fused trimeric all-beta dUTPase involve a catalytically competent fused dimeric intermediate. FEBS J. 2016, 283, 3268-3286. [CrossRef] [PubMed]

33. Berman, H.M.; Westbrook, J.; Feng, Z.; Gilliland, G.; Bhat, T.N.; Weissig, H.; Shindyalov, I.N.; Bourne, P.E. The Protein Data Bank. Nucleic Acids Res. 2000, 28, 235-242. [CrossRef] [PubMed]

34. UniProt, C. UniProt: A worldwide hub of protein knowledge. Nucleic Acids Res. 2019, 47, D506-D515.

35. Sievers, F.; Wilm, A.; Dineen, D.; Gibson, T.J.; Karplus, K.; Li, W.; Lopez, R.; McWilliam, H.; Remmert, M.; Soding, J.; et al. Fast, scalable generation of high-quality protein multiple sequence alignments using Clustal Omega. Mol. Syst. Biol. 2011, 7, 539. [CrossRef]

36. Kabsch, W. Integration, scaling, space-group assignment and post-refinement. Acta Crystallogr. D Biol. Crystallogr. 2010, 66, 133-144. [CrossRef]

37. Adams, P.D.; Afonine, P.V.; Bunkoczi, G.; Chen, V.B.; Davis, I.W.; Echols, N.; Headd, J.J.; Hung, L.W.; Kapral, G.J.; Grosse-Kunstleve, R.W.; et al. PHENIX: A comprehensive Python-based system for macromolecular structure solution. Acta Crystallogr. D Biol. Crystallogr. 2010, 66, 213-221. [CrossRef]

38. Winn, M.D.; Ballard, C.C.; Cowtan, K.D.; Dodson, E.J.; Emsley, P.; Evans, P.R.; Keegan, R.M.; Krissinel, E.B.; Leslie, A.G.; McCoy, A.; et al. Overview of the CCP4 suite and current developments. Acta Crystallogr. D Biol. Crystallogr. 2011, 67, 235-242. [CrossRef]

39. Murshudov, G.N.; Vagin, A.A.; Dodson, E.J. Refinement of macromolecular structures by the maximum-likelihood method. Acta Crystallogr. D Biol. Crystallogr. 1997, 53, 240-255. [CrossRef]

40. Winn, M.D.; Isupov, M.N.; Murshudov, G.N. Use of TLS parameters to model anisotropic displacements in macromolecular refinement. Acta Crystallogr. D, Biol. Crystallogr. 2001, 57, 122-133. [CrossRef]

41. The PyMOL Molecular Graphics System; Version 2.1.0; Schrödinger, LLC: New York, NY, USA.

42. Lakowicz, J. Principles of Fluorescence Spectroscopy, 2nd ed.; Springer: New York, NY, USA, 1999; pp. 237-251, 291-306. 
43. Toth, J.; Varga, B.; Kovacs, M.; Malnasi-Csizmadia, A.; Vertessy, B.G. Kinetic mechanism of human dUTPase, an essential nucleotide pyrophosphatase enzyme. J. Biol. Chem. 2007, 282, 33572-33582. [CrossRef] [PubMed]

44. Lopata, A.; Leveles, I.; Bendes, A.A.; Viskolcz, B.; Vertessy, B.G.; Jojart, B.; Toth, J. A Hidden Active Site in the Potential Drug Target Mycobacterium tuberculosis dUTPase Is Accessible through Small Amplitude Protein Conformational Changes. J. Biol. Chem. 2016, 291, 26320-26331. [CrossRef] [PubMed]

45. Matulis, D.; Kranz, J.K.; Salemme, F.R.; Todd, M.J. Thermodynamic stability of carbonic anhydrase: Measurements of binding affinity and stoichiometry using ThermoFluor. Biochemistry 2005, 44, 5258-5266. [CrossRef] [PubMed]

46. Pecsi, I.; Leveles, I.; Harmat, V.; Vertessy, B.G.; Toth, J. Aromatic stacking between nucleobase and enzyme promotes phosphate ester hydrolysis in dUTPase. Nucleic Acids Res 2010, 38, 7179-7186. [CrossRef] [PubMed]

(C) 2019 by the authors. Licensee MDPI, Basel, Switzerland. This article is an open access article distributed under the terms and conditions of the Creative Commons Attribution (CC BY) license (http://creativecommons.org/licenses/by/4.0/). 